\title{
Sentiment Analysis of User on the basis of Listened Songs
}

\author{
Umang Rastogi \\ Department of CSE, MIET, Meerut
}

\author{
Shubham Goel \\ Department of CSE, MIET, Meerut
}

\author{
Venkat Maan \\ Department of CSE, MIET, Meerut
}

\author{
Utkarsh Agarwal \\ Department of CSE, MIET, Meerut
}

\author{
Varchsva Arya \\ Department of CSE, MIET, Meerut
}

\author{
Ajay Kumar Singh \\ Department of CSE, MIET, Meerut
}

\begin{abstract}
In this paper, an algorithm is proposed to detect the sentiments of the user who listen the song. This project can be used to perform emotional analysis of a person on the basis of songs /Music listened by him and that analysis can be further used to predict the sentiments and mood of that person. This application can be used by different websites to recommend the songs, music or videos on the basis of sentiments of users detected by this application.
\end{abstract}

\section{Keywords}

Sentiment Analysis, Sentiment Detection, Mood, Minimum Sentiment, Maximum Sentiment.

\section{INTRODUCTION}

\subsection{Introduction of project}

In general, Sentiment Analysis is defined as opinion mining. Objective of which is to analyse the emotions, thoughts, feelings or moods of a person on a certain topic or a thing. A lot of work related to sentiment mining is going on in various fields including social network platforms, E-Commerce Feedbacks, Movie Reviews etc [1].

The best way to express human feelings is music [2]. A person easily gets connected to music that fits in his

Current scenario. Today, mostly all the popular music compositions which have vocals have a text attached to them called lyrics. These lyrics can be analyzed as a dataset consisting of thoughts, moods, emotions, believes or feelings related to certain topics [3]. Words or Lyrics is the soul of song, songs might feel like soul less in absence of good lyrics. Songs with more powerful lyrics seems to stick in our mind while songs with less powerful lyrics seem to fade away easily.

In the study conducted as Music v/s Lyrics by V. Stratton and A. Zalanowski, [4] It has been observed that lyrics are having a greater power to direct mood change then music alone.

Recently, People are living in the flow of media. Specially, music is one of the most popular media. In general, songs are closely related with emotion and mood. Sometimes, people select songs which they want to listen to according to their mood. However, it is not an easy task to find manually the music what they want because there are so many songs. Therefore, a music classification and recommendation system is needed [5]. Till now, many researchers have tried to analyze the sentiments involved in songs on the basis of their lyrics.

The main purpose of the application is to identify the emotions, sentiments of our audience. On the basis of the songs listened by the listeners, the application will identify the maximum and minimum sentiment of the particular listener. For ascertaining these sentiments, approximate sample of at least 30-50 songs listened by the user is required to be taken to come to any conclusion.

\subsection{Scope}

Sentiment analysis [6] is a topic of great interest and development since it has many practical applications. Companies use sentiment analysis to automatically analyze survey responses, product reviews, social media comments, and like to get valuable insights about their brands, product and services. Sentiment analysis is the procedure by which information is extracted from the opinions, appraisals and emotions of people in regards to entities, events and their attributes. In decision making, the opinions of others have a significant effect on customers ease, making choices with regards to online shopping, choosing events, products, entities [7]. Sentiment analysis results are in fact widely used as a component of recommendation engines that generate advertisements for online users in many websites.

Sentiment analysis is starting to be explored in music recommendation systems to suggest a specific song depending on the emotional state of a person, since the song is totally related to the current emotion and feelings of the person [8].

The main objective of the application is to mine the sentiment from lyrics of the song and to get valuable insights of user or to know about the user attitude on the basis of this sentiment. Using this application system, everyone can automatically analyze the insights of user and on the basis users insights, system can easily percept data required by user and provide them.

\section{PROPOSED WORK PLAN}

2.1 The main objective of the application to detect the sentiments of the listener of songs on the basis of song listened by him.

A Data Flow Diagram shows what kind of information to input and output from the system, where the data will come from and go to, and where the data will be stored as shown in figure 1 and figure 2. 


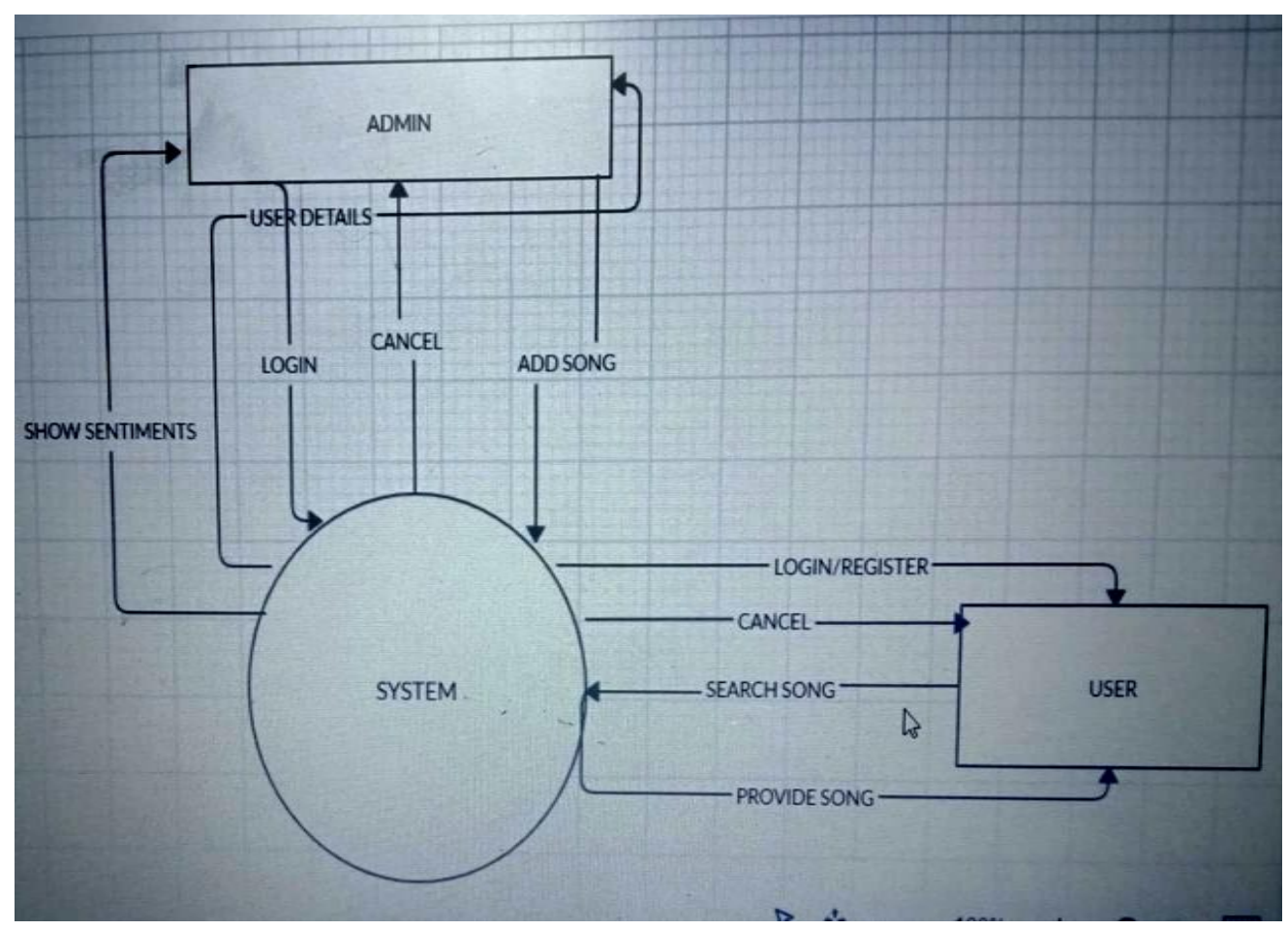

Fig. 1 Level 0 Data Flow Diagram

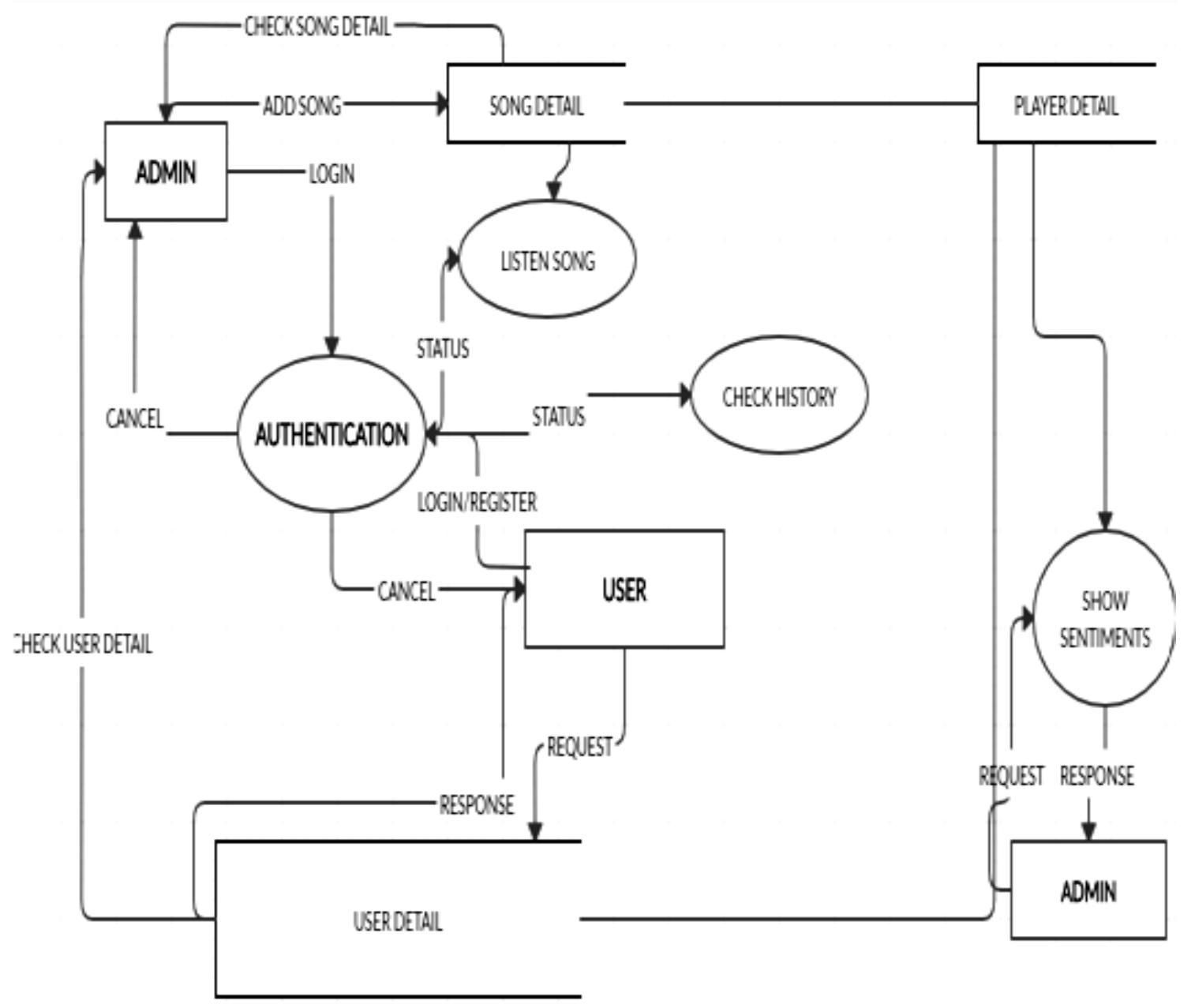

Fig. 2 -Level 1 Data Flow Diagram 
Figure 2 clearly shows that authentication [9-10] plays vital role in our paper.

\subsection{Algorithm of main complement of the system}

The main purpose of the application is to detect the sentiments of user on the basis of songs listened by them. To detect sentiments [11], an algorithm has been designed, which is given as follow:

\section{Sentiment Detection Algorithm}

1. There has been defined a unique ID and the category such as very sad, sad, normal, happy, very happy and romantic for each song in song table.

2. When a particular user listen song of a particular category, 1 get add to that category .

3. Similarly loop will run again unless user exit or stop listening song.

4. Now an array of frequencies of each category song listened by user is obtained

5. To define Maximum sentiments - run Get_Max _Algorithm(array).

6. To define Minimum sentiments - run Get_Min _Algorithm(array).

7. To define Mood - run Mood_Algorithm(array).

These functions are given below.

\section{Get_Max_Algorithm(array)}

- Input- an array of frequencies for each category of song listened by a particular user.

- Define a mood array that is the collection of all possible sentiments.

- Initialize a variable $\mathrm{K}$ which define the location of array element at which maximum frequency exist. Initially $\mathrm{K}$ set to 0 .

- $\quad$ Let $\mathrm{I}=0$

- for I= 0 to array _length

$\circ \quad \operatorname{if}(\operatorname{array}[\mathrm{K}]<\operatorname{array}[\mathrm{I}])$

○ $\mathrm{K}=\mathrm{I}$

○ $\quad \mathrm{I}=\mathrm{I}+1$

- $\quad$ End of for loop.
- $\quad$ Return $\operatorname{mood}[\mathbf{K}]$

\section{Get_Min_Algorithm(array)}

- Input- an array of frequencies for each category of song listened by a particular user.

- Define a mood array that is the collection of all possible sentiments.

- Initialize a variable $\mathrm{K}$ which define the location of array element at which maximum frequency exist. Initially $\mathrm{K}$ set to 0 .

- Let $\mathrm{I}=0$

- for I= 0 to array _length

$$
\begin{array}{ll}
\circ & \text { if }(\operatorname{array}[\mathrm{K}]>\operatorname{array}[\mathrm{I}]) \\
\circ & \mathrm{K}=\mathrm{I} \\
\circ & \mathrm{I}=\mathrm{I}+1
\end{array}
$$

- $\quad$ End of for loop.

- $\quad$ Return $\operatorname{mood}[\mathbf{K}]$

Mood_Algorithm(array)

- Input- an array of frequencies for each category of song listened by a particular user.

- Define a mood array that is the collection of all possible sentiments.

- Generate copy array (let array1 ) of array and sort array1.

- $\quad$ Find the median of array1.

- $\quad$ Let $\mathrm{K}=0$

- $\quad$ Let $\mathrm{I}=0$

- Let Median=location of element of array1 at which median value of array1 exist.

- for I=0 to array_length

$$
\begin{array}{ll}
\circ & \text { if }(\operatorname{array1}[\text { Median] }==\operatorname{array}[\mathrm{I}] \text { ) } \\
\circ & \mathrm{K}=\mathrm{I} \\
\circ & \mathrm{I}=\mathrm{I}+1
\end{array}
$$

- $\quad$ End of for loop.

- $\quad$ Return $\operatorname{mood}[\mathbf{K}]$

\section{EXPERIMENT RESULT ANALYSIS}

\subsection{Description of data set used.}

Figure 3 shows the player information that is used for experiment result analysis. 


\begin{tabular}{|c|c|c|c|c|c|c|c|}
\hline UName $\nabla 1$ & SID & PDate & PTime & KRISHNA2 & 13 & 2020-05-08 & $19: 13: 00$ \\
\hline KRISHNA2 & 10 & $2020-05-11$ & $10: 32: 00$ & KRISHNA2 & 1 & 2020-05-08 & $19: 12: 00$ \\
\hline KRISHNA2 & 8 & 2020-05-08 & $18: 39: 00$ & KRISHNA2 & 4 & 2020-05-08 & $19: 10: 00$ \\
\hline KRISHNA2 & 9 & 2020-05-08 & 18:38:00 & KRISHNA2 & 10 & 2020-05-08 & $19: 07: 00$ \\
\hline KRISHNA2 & 14 & $2020-05-08$ & $18: 36: 00$ & KRISHNA2 & 8 & 2020-05-08 & 19:03:00 \\
\hline KRISHNA2 & 15 & 2020-05-08 & $18 \cdot 34 \cdot 00$ & KRISHNA2 & 14 & 2020-05-08 & $18: 58: 00$ \\
\hline KRISHINAL & 15 & 2020-05-08 & 18.34.00 & KRISHNA2 & 15 & 2020-05-08 & $18: 54: 00$ \\
\hline KRISHNA2 & 16 & 2020-05-08 & $18: 33: 00$ & KRISHNA2 & 1 & 2020-05-08 & 18:51:00 \\
\hline KRISHNA2 & 12 & 2020-05-08 & $18: 29: 00$ & KRISHNA2 & 13 & 2020-05-08 & $18: 47: 00$ \\
\hline KRISHNA2 & 11 & 2020-05-08 & $18: 28: 00$ & KRISHNA2 & 13 & $2020-05-08$ & $18: 45: 00$ \\
\hline KRISHNA2 & 10 & 2020-05-08 & $18: 26: 00$ & KRISHNA2 & 15 & $2020-05-08$ & $17: 58: 00$ \\
\hline KRISHNA2 & 8 & 2020-05-08 & $18: 24: 00$ & KRISHNA2 & 14 & 2020-05-08 & $17: 57: 00$ \\
\hline KRISHNA2 & 4 & $2020-05-08$ & 18:21:00 & KRISHNA2 & 9 & 2020-05-08 & $17: 56: 00$ \\
\hline KRISHNA2 & 16 & 2020-05-08 & $18: 02: 00$ & KRISHNA2 & 9 & 2020-05-08 & $19: 00: 00$ \\
\hline KRISHNA2 & 10 & $2020-05-08$ & $18: 41: 00$ & KRISHNA2 & 18 & 2020-05-08 & $18: 31: 00$ \\
\hline KRISHNA2 & 11 & 2020-05-08 & $18: 42: 00$ & KRISHNA2 & 13 & $2020-05-08$ & $17: 49: 00$ \\
\hline KRISHNA2 & 12 & 2020-05-08 & $18: 44: 00$ & KRISHNA2 & 10 & $2020-05-08$ & $17: 52: 00$ \\
\hline KRISHNA2 & 5 & $2020-05-11$ & $10: 08: 00$ & KRISHNA2 & 8 & 2020-05-08 & $17: 54: 00$ \\
\hline
\end{tabular}

\section{Fig. 3 Player Information}

Figure 4 shows songs with category that are available for user to listen

\begin{tabular}{|c|c|c|c|c|c|c|c|c|c|c|c|}
\hline SID & Title & Singer & Music & MusicFile & VerySad & Sad & Normal & Happy & VeryHappy & Romantic & Dance \\
\hline 1 & Jiya Dhadak & Unknown & Unknown & $\begin{array}{l}02 \text { - Jiya Dhadak Dhadak } \\
\text { Jaye-(MyMp3Singer.com)-1.m... }\end{array}$ & 0 & 0 & 1 & 0 & 0 & 1 & 0 \\
\hline 2 & TU JAANE NA & SING1 & $\begin{array}{l}\text { AJAB PREM KE } \\
\text { GAJAB KAHANI }\end{array}$ & 08.Tu Jaane Na - Reprise.mp3 & 0 & 0 & 1 & 0 & 0 & 1 & 0 \\
\hline 3 & KABHI JO BADAL & ARJIT SINGH & MOVIE2 & Kabhi Jo Baadal Barse - Arijit Singh.mp3 & 0 & 1 & 0 & 0 & 0 & 1 & 0 \\
\hline 4 & CHAND SIFARISH & UNKNOWN & FANA & $\begin{array}{l}\text { Chand Siffarish-Shaan- } \\
\text { www.Mp3Mad.Com.mp3 }\end{array}$ & 0 & 0 & 0 & 1 & 0 & 1 & 0 \\
\hline 5 & $A B C$ & UNKNOWN & MOVIE3 & AUD-20200405-WA0010.mp3 & 0 & 0 & 0 & 1 & 0 & 0 & 1 \\
\hline 6 & $\mathrm{ABC1}$ & UNKNOWN & MOVIE4 & AUD-20200405-WA0011.mp3 & 0 & 0 & 0 & 1 & 0 & 0 & 1 \\
\hline 7 & $\mathrm{ABC2}$ & UNKNOWN & MOVIE5 & AUD-20200405-WA0012.mp3 & 0 & 0 & 1 & 0 & 0 & 0 & 1 \\
\hline 13 & Aaja Ki Intezar Mai & Mohd Rafi & MOVIE200 & Halaku - Aaja Ki Intezar Mein.mp3 & 0 & 0 & 1 & 0 & 0 & 1 & 0 \\
\hline 12 & Aaja Jaane Ja Mere & Asha Bhosle & movie108 & GGPN-Aaja Jaane.mp3 & 0 & 1 & 0 & 0 & 0 & 1 & 0 \\
\hline 11 & $\begin{array}{l}\text { Aap Ki Yaad Aati } \\
\text { Rahi }\end{array}$ & Chhaya Ganguli & movie105 & Gaman-Aap Ki Yaad.mp3 & 1 & 0 & 0 & 0 & 0 & 0 & 0 \\
\hline 10 & $\begin{array}{l}\text { Aankhon Mein Kyun } \\
\text { Nami Hai }\end{array}$ & $\begin{array}{l}\text { Rahat Fateh Ali } \\
\text { Khan }\end{array}$ & MOVIE104 & DBD-Aankhon Mein.mp3 & 1 & 0 & 0 & 0 & 0 & 0 & 0 \\
\hline 8 & Aadat & Atif Aslam & Movie100 & 02 - Aadat (Jal Band) - Kalyug (2005).mp3 & 0 & 1 & 0 & 0 & 0 & 0 & 0 \\
\hline 9 & Thi Mari Dastan & $\begin{array}{l}\text { Amit Sana, } \\
\text { Anuradha }\end{array}$ & movie102 & 06 - Thi Meri Dastan - Kalyug (2005).mp3 & 0 & 0 & 1 & 0 & 0 & 1 & 0 \\
\hline 14 & $\begin{array}{l}\text { Aaj Socha To } \\
\text { Aansoo }\end{array}$ & $\begin{array}{l}\text { Lata } \\
\text { Mangeshkar }\end{array}$ & movie201 & HZ-Aaj Socha To.mp3 & 1 & 0 & 0 & 0 & 0 & 0 & 0 \\
\hline 15 & Aa Ab Laut Ke Aaja & $\begin{array}{l}\text { Anuradha } \\
\text { Paudwal }\end{array}$ & movie202 & IKH-Aa Ab Laut Ke Aaja.mp3 & 0 & 1 & 0 & 0 & 0 & 0 & 0 \\
\hline 16 & Aansoo Ab Tum & Lata & Movie203 & Kafila-Aansoo Ab Tum.mp3 & 0 & 1 & 0 & 0 & 0 & 0 & 0 \\
\hline
\end{tabular}

Fig. 4 Song Table 
Table 1 - Category of song along with their corresponding Mood

\begin{tabular}{|c|c|}
\hline Category & Corresponding Mood \\
\hline Very Sad & Very Sad \\
\hline Sad & Sad \\
\hline Normal & Normal \\
\hline Happy & Happy \\
\hline Very Happy & Very Happy \\
\hline Romantic & Romantic \\
\hline Dance & Joyful \\
\hline
\end{tabular}

\subsection{Efficiency or accuracy of designed} system

Here the sentiments of a user has been analyzed manually by applying same concept on the basis of which algorithm has been designed to obtain expected output to check the efficiency or accuracy of the system by comparing the actual output with expected output:

-User Name: Krishna2

-Details of songs listened by him shown in Table 1 .

Table 2 - Song listened by user - KRISHNA2 \& their categorization

\begin{tabular}{|c|c|c|c|c|c|c|c|c|c|}
\hline \multirow[t]{2}{*}{ SID } & \multirow[t]{2}{*}{ Title } & \multirow[t]{2}{*}{ Singer } & \multicolumn{7}{|c|}{ Category } \\
\hline & & & $\begin{array}{l}\text { Very } \\
\text { Sad }\end{array}$ & Sad & Normal & Happy & $\begin{array}{c}\text { Very } \\
\text { Happy }\end{array}$ & Romantic & Dance \\
\hline 1 & Jiya Dhadak & $\begin{array}{c}\text { Rahat } \\
\text { Fateh Ali } \\
\text { Khan }\end{array}$ & 0 & 0 & 1 & 0 & 0 & 1 & 0 \\
\hline 4 & $\begin{array}{l}\text { CHAND } \\
\text { SIFARISH }\end{array}$ & $\begin{array}{c}\text { Shaan, } \\
\text { Kailash } \\
\text { Kher }\end{array}$ & 0 & 0 & 0 & 1 & 0 & 1 & 0 \\
\hline 5 & Viah & $\begin{array}{c}\text { Jass } \\
\text { Manak }\end{array}$ & 0 & 0 & 0 & 1 & 0 & 0 & 1 \\
\hline 8 & Aadat & Atif Aslam & 0 & 1 & 0 & 0 & 0 & 0 & 0 \\
\hline 9 & $\begin{array}{l}\text { Thi Mari } \\
\text { Dastan }\end{array}$ & $\begin{array}{c}\text { Amit Sana, } \\
\text { Anuradha }\end{array}$ & 0 & 0 & 1 & 0 & 0 & 1 & 0 \\
\hline 10 & $\begin{array}{l}\text { Aankhon } \\
\text { Mein Kyun } \\
\text { Nami Hai }\end{array}$ & $\begin{array}{c}\text { Rahat } \\
\text { Fateh Ali } \\
\text { Khan }\end{array}$ & 1 & 0 & 0 & 0 & 0 & 0 & 0 \\
\hline 11 & $\begin{array}{c}\text { Aap Ki } \\
\text { Yaad Aati } \\
\text { Rahi }\end{array}$ & $\begin{array}{l}\text { Chhaya } \\
\text { Ganguli }\end{array}$ & 1 & 0 & 0 & 0 & 0 & 0 & 0 \\
\hline 12 & $\begin{array}{l}\text { Aaja Jaane } \\
\text { Ja Mere }\end{array}$ & $\begin{array}{c}\text { Asha } \\
\text { Bhosle }\end{array}$ & 0 & 1 & 0 & 0 & 0 & 1 & 0 \\
\hline 13 & $\begin{array}{c}\text { Aaja Ki } \\
\text { Intezar Mai }\end{array}$ & Mohd Rafi & 0 & 0 & 1 & 0 & 0 & 1 & 0 \\
\hline 14 & $\begin{array}{l}\text { Aaj Socha } \\
\text { To Aansoo }\end{array}$ & $\begin{array}{c}\text { Lata } \\
\text { Mangeshk } \\
\text { ar }\end{array}$ & 1 & 0 & 0 & 0 & 0 & 0 & 0 \\
\hline 15 & $\begin{array}{c}\text { Aa Ab Laut } \\
\text { Ke Aaja }\end{array}$ & $\begin{array}{c}\text { Anuradha } \\
\text { Paudwal }\end{array}$ & 0 & 1 & 0 & 0 & 0 & 0 & 0 \\
\hline 16 & $\begin{array}{c}\text { Aansoo Ab } \\
\text { Tum Kabhi } \\
\mathrm{Na}\end{array}$ & $\begin{array}{c}\text { Lata } \\
\text { Mangeshk } \\
\text { ar }\end{array}$ & 0 & 1 & 0 & 0 & 0 & 0 & 0 \\
\hline 18 & $\begin{array}{l}\text { Aa Bhi Ja } \\
\text { Sanam }\end{array}$ & Atif Aslam & 0 & 1 & 0 & 0 & 0 & 1 & 0 \\
\hline
\end{tabular}


As per the underlying concept, if a user listen a song ' $n$ ' number of times which has been categorized as romantic count goes to romantic ' $n$ ', similarly for other song listened by him, from which the following information will be obtained which is shown in Table 2.

Table 3 - Frequency Table

\begin{tabular}{|c|c|c|c|c|c|c|c|c|c|c|}
\hline \multirow{2}{*}{$\begin{array}{l}\text { SI } \\
\text { D }\end{array}$} & \multirow[t]{2}{*}{ Title } & \multirow[t]{2}{*}{ Singer } & \multirow{2}{*}{$\begin{array}{l}\text { No of Times the } \\
\text { user listened the } \\
\text { particular song }\end{array}$} & \multicolumn{7}{|c|}{ Category } \\
\hline & & & & $\begin{array}{l}\text { Very } \\
\text { Sad }\end{array}$ & Sad & Normal & Happy & $\begin{array}{c}\text { Very } \\
\text { Happy }\end{array}$ & Romantic & Dance \\
\hline 1 & $\begin{array}{c}\text { Jiya } \\
\text { Dhadak }\end{array}$ & $\begin{array}{c}\text { Rahat } \\
\text { Fateh Ali } \\
\text { Khan }\end{array}$ & 2 & 0 & 0 & 2 & 0 & 0 & 2 & 0 \\
\hline 4 & $\begin{array}{l}\text { CHAND } \\
\text { SIFARISH }\end{array}$ & $\begin{array}{l}\text { Shaan, } \\
\text { Kailash } \\
\text { Kher }\end{array}$ & 2 & 0 & 0 & 0 & 2 & 0 & 2 & 0 \\
\hline 5 & Viah & $\begin{array}{c}\text { Jass } \\
\text { Manak }\end{array}$ & 1 & 0 & 0 & 0 & 1 & 0 & 0 & 1 \\
\hline 8 & Aadat & $\begin{array}{c}\text { Atif } \\
\text { Aslam }\end{array}$ & 4 & 0 & 4 & 0 & 0 & 0 & 0 & 0 \\
\hline 9 & $\begin{array}{l}\text { Thi Mari } \\
\text { Dastan }\end{array}$ & $\begin{array}{c}\text { Amit } \\
\text { Sana, } \\
\text { Anuradha }\end{array}$ & 3 & 0 & 0 & 3 & 0 & 0 & 3 & 0 \\
\hline 10 & $\begin{array}{l}\text { Aankhon } \\
\text { Mein } \\
\text { Kyun } \\
\text { Nami Hai }\end{array}$ & $\begin{array}{c}\text { Rahat } \\
\text { Fateh Ali } \\
\text { Khan }\end{array}$ & 5 & 5 & 0 & 0 & 0 & 0 & 0 & 0 \\
\hline 11 & $\begin{array}{c}\text { Aap Ki } \\
\text { Yaad Aati } \\
\text { Rahi }\end{array}$ & $\begin{array}{l}\text { Chhaya } \\
\text { Ganguli }\end{array}$ & 2 & 2 & 0 & 0 & 0 & 0 & 0 & 0 \\
\hline 12 & $\begin{array}{l}\text { Aaja Jaane } \\
\text { Ja Mere }\end{array}$ & $\begin{array}{c}\text { Asha } \\
\text { Bhosle }\end{array}$ & 2 & 0 & 2 & 0 & 0 & 0 & 2 & 0 \\
\hline 13 & $\begin{array}{l}\text { Aaja Ki } \\
\text { Intezar } \\
\text { Mai }\end{array}$ & $\begin{array}{l}\text { Mohd } \\
\text { Rafi }\end{array}$ & 4 & 0 & 0 & 4 & 0 & 0 & 4 & 0 \\
\hline 14 & $\begin{array}{l}\text { Aaj Socha } \\
\text { To Aansoo }\end{array}$ & $\begin{array}{c}\text { Lata } \\
\text { Mangesh } \\
\text { kar }\end{array}$ & 3 & 3 & 0 & 0 & 0 & 0 & 0 & 0 \\
\hline 15 & $\begin{array}{c}\mathrm{Aa} \mathrm{Ab} \\
\text { Laut Ke } \\
\text { Aaja }\end{array}$ & $\begin{array}{c}\text { Anuradha } \\
\text { Paudwal }\end{array}$ & 3 & 0 & 3 & 0 & 0 & 0 & 0 & 0 \\
\hline 16 & $\begin{array}{c}\text { Aansoo } \\
\text { Ab Tum } \\
\text { Kabhi Na }\end{array}$ & $\begin{array}{c}\text { Lata } \\
\text { Mangesh } \\
\text { kar }\end{array}$ & 2 & 0 & 2 & 0 & 0 & 0 & 0 & 0 \\
\hline 18 & $\begin{array}{l}\text { Aa Bhi Ja } \\
\text { Sanam }\end{array}$ & $\begin{array}{c}\text { Atif } \\
\text { Aslam }\end{array}$ & 1 & 0 & 1 & 0 & 0 & 0 & 1 & 0 \\
\hline & & Total & & 10 & 12 & 9 & 3 & $\mathbf{0}$ & 14 & 1 \\
\hline
\end{tabular}

Table 3 shows the total of frequencies of each category of songs listened by user Krishna2 which has been displayed in

Table 4 along with their corresponding mood.

Table 4 -Summarisation of Frequency Table

\begin{tabular}{|c|c|c|}
\hline Category & Frequency of Category & Corresponding Mood \\
\hline Very Sad & 10 & Very Sad \\
\hline Sad & 12 & Nad \\
\hline Normal & 9 & Normal \\
\hline
\end{tabular}




\begin{tabular}{|c|c|c|}
\hline Happy & 3 & Happy \\
\hline Very Happy & 0 & Very Happy \\
\hline Romantic & 14 & Romantic \\
\hline Dance & 1 & Joyful \\
\hline
\end{tabular}

From the Table 4, Maximum and minimum frequency can be extracted. Maximum Frequency in case of User 'KRISHNA2' is 14 whose category is Romantic and Corresponding mood is Romantic so the maximum sentiment of KRISHNA2 is Romantic.

Similarly the minimum frequency in case of User 'KRIS

HNA2' is 0 whose category is Very Happy and
Corresponding mood is very happy so the minimum sentiment of KRISHNA2 is very happy.

To estimate the mood, the median of frequency of category is calculated. For User KRISHNA2, the median is 9 whose category is Normal and Corresponding mood is Normal so the mood of KRISHNA2 is Normal.

Table 5 - Expected Output

\begin{tabular}{|c|c|c|}
\hline \multicolumn{3}{|c|}{ Expected Output- for user KRISHNA2 } \\
\hline Maximum Sentiment & Minimum Sentiment & Mood \\
\hline Romantic & Very Happy & Normal \\
\hline
\end{tabular}

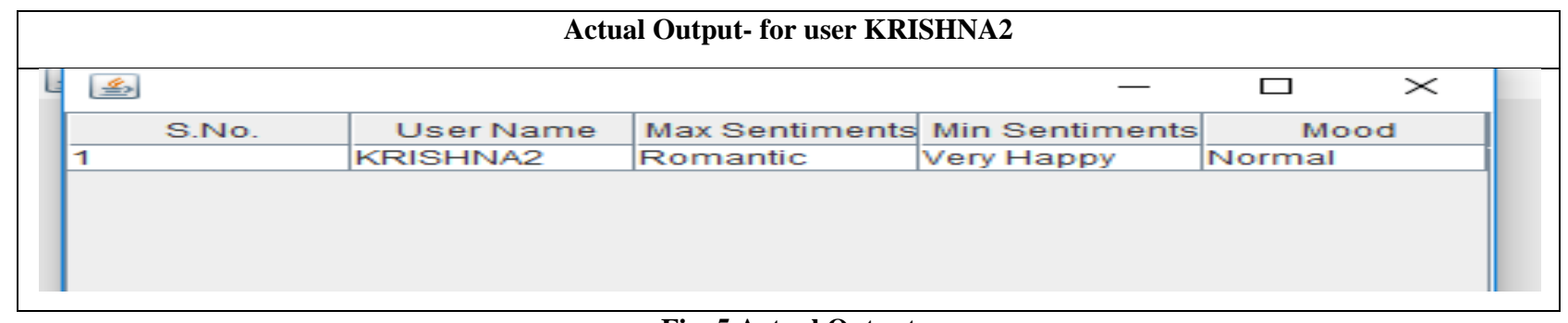

Fig. 5 Actual Output

By comparing actual output as shown in figure 5 and expected output as shown in Table 5, it is concluded that the application designed is efficient and providing correct output.

\section{CONCLUSION}

Music is the best form to express the feeling it also conveys that what the composer want to give message to listener. Human easily connected to music with current thought of mind.

The designed application worked on the same principle. In which it has been trying to establish a connection between songs / music listened by user and his / her sentiments and mood. On probability based the proposed application is to identify the minimum and maximum sentiments and their moods. How much bigger will be the sample data taken for analysis, result will be more accurate. The output of the said application is just an estimation which cannot be ensured with $100 \%$ surety.

On the basis of those sentiments, Anyone can recommend the play list of songs, movies or videos which will help the user to select the song / movie or videos of his/ her interest with ease which makes the system more interactive. The user will also be noticed of songs that are not being played, to help them free up storage space. On similar concept, other recommendations and advertisements can be made available to user which will benefit the both, user get data/ information of his / her interest and businesses and other entities, whether service or product based, will get customer.

\section{REFERENCES}

[1] Apoorv Agarwal, Renu Dhir, Geeta Sikka, Vivek Sharma: Sentiments mining and classification of music lyrics using SentiWordNet, 2016 Symposium on Colossal Data Analysis and Networking (CDAN), IEEE, 2016.

[2] Mahesh Ahuja, A. L. Sangal, "Opinion mining and classification of music lyrics using supervised learning algorithms", 2018 First International Conference on Secure Cyber Computing and Communication (ICSCCC).

[3] B. Logan, A. Kositsky and P. Moreno, "Semantic analysis of song lyrics", 2004 IEEE International Conference on Multimedia and Expo (ICME) (IEEE Cat. No.04TH8763).

[4] V. Stratton and A. Zalanowski, "Affective Impact of Music vs. Lyrics", Empirical Studies of the Arts, vol. 12, no. 2, pp. 173-184, 1994.

[5] S. Oh, M. Hahn and J. Kim, "Music Mood Classification Using Intro and Refrain Parts of Lyrics", 2013 International Conference on Information Science and Applications (ICISA), 2013.

[6] Bing Liu., "Sentiment Analysis and Opinion Mining", Morgan \& Claypool Publishers.

[7] H. Binali, V. Potdar and C. Wu, "A state of the art opinion mining and its application domains", 2009 IEEE International Conference on Industrial Technology, 2009. 
[8] Demóstenes Zegarra Rodríguez, Graça Bressan and Renata Lopes Rosa, "Music Recommendation System Based on User's Sentiments Extracted from Social Networks" ,Department of Computer Science and Digital Systems - University of São Paulo São Paulo, Brazil.

[9] Saurabh Yadav and Ajay Kumar Singh, "A Biometric Traits Based Authentication System for Indian Voting System," International Journal of Computer Application (IJCA), ISSN: 0975-8887, vol. 65, no.15, pp. 159-162, March 2013. doi: 10.5120/11002-6185.
[10] Sharu Goel and Ajay Kumar Singh, "QR Code Implementation in Photo I-Card for Photo and Text Credentials using .NET," International Journal of Computer Applications, Innovations in Computing and Information Technology (Cognition 2015), ISSN: 09758887, pp. 20-24, August 2014

[11] Erik Cambria, Dipankar Das, Sivaji Bandyopadhyay, Antonio Feraco, "A Practical Guide to Sentiment Analysis”, Springer International Publishing AG 2017. 